\title{
The Effect of Butyric Acid on GLUT4 and IRS1 Expression in Human Preadipocytes in vitro
}

\author{
L. R. Maness \\ Department of Clinical Laboratory Science, Winston-Salem State University, USA
}

Copyright $\bigcirc 2016$ by authors, all rights reserved. Authors agree that this article remains permanently open access under the terms of the Creative Commons Attribution License 4.0 international License.

\begin{abstract}
Understanding the dietary components that can prevent and treat diabetes mellitus types 2 (DMT2) is important to millions of people who are at risk for and currently suffer from the various aspects of this disease. Our diets can affect our health at the level of gene expression, thus, determining foods that can positively affect cellular activity can be advantageous to our daily lives. Butyric acid is a fatty acid that can be fermented from fiber by beneficial intestinal bacteria. This substance has been shown to improve insulin sensitivity and metabolic activity in mice and to affect genes involved in the insulin pathway both in cell culture and in mice. This study determined the effect of butyric acid on the expression of two genes important to insulin sensitivity, glucose transporter 4 (GLUT4) and insulin receptor substrate 1 (IRS1), in human preadipocytes in vitro. Butyric acid at concentrations $0.05 \mathrm{mg} / \mathrm{ml}, 0.1$ $\mathrm{mg} / \mathrm{ml}$, and $1.0 \mathrm{mg} / \mathrm{ml}$ each increased the expression of both of these genes, indicating that cells are more sensitive to insulin in the presence of this component. This study indicates that butyric acid can be implemented into dietary plans to prevent and control DMT2 by increasing daily fiber intake.
\end{abstract}

Keywords GLUT4, IRS1, Diabetes Mellitus Type 2, Butyric Acid, Preadipocytes

\section{Introduction}

Affecting over 29 million Americans, diabetes mellitus type 2 (DMT2) is one of the most debilitating disease in the U.S. [1]. Patients with this disease experience a variety of health problems including neuropathy, kidney disease, skin and eye complications, stroke, and cardiovascular disease [2]. Ongoing research toward controlling and preventing DMT2 is immensely important since there are over 1 million cases diagnosed each year in this country alone [1]. It has been shown that physical activity and healthy eating habits can prevent the disease and these lifestyle traits can also go a long way in easing the progression of side effects
[3].

Butyric acid is a short chain fatty acid that can be found in butter, but is also produced in the intestines by bacteria that ferment non-digestible carbohydrates [4,5]. Examples of these beneficial bacteria are Roseburia spp. and Eubacterium spp. [6]. High levels of fat in the diet have been shown to decrease levels of butyric acid, while high levels of dietary fiber have been found to increase its levels $[7,8]$. This molecule has been shown to not only improve the health of patients with irritable bowel syndrome, but also those with colon cancer, hemoglobinopathies, and diabetes [9-11]. Butyrate supplementation in C57BL/6 J mice has been shown to improve mitochondrial activity, prevent obesity, and improve insulin sensitivity [11]. In addition, diabetic male Wistar rats given daily doses of butyric acid showed improvement of blood and urine glucose and also lost weight [12].

Studies of human cells in vitro have shown that butyric acid affects cells at the level of gene expression $[13,14]$. One such study showed that Caco-2 cells exposed to this carboxylic acid had increases in the expression of glucose- 6 phophatase, catalytic subunit (G6PC) and phosphoenolpyruvate carboxykinase 1 (PCK1), among others [13]. Each of these genes is important to the insulin pathway. Similar research indicated that butyric acid has an effect on insulin sensitivity of human hepatocytes by increasing the expression of glucose transporter 2 (GLUT2) and insulin receptor substrate 1 (IRS1) [14].

The aim of this study was to determine if the same concentrations of butyric acid have a similar effect on the expression of IRS1 and glucose transporter 4 (GLUT4) in insulin-resistant human preadipocytes in vitro as with human hepatocytes. In liver cells, the specific glucose transporter gene is GLUT2, while in adipose cells the isoform is GLUT4, but they serve the same purpose of beginning the process of bringing glucose into the cell $[14,15]$. Since the GLUT gene transports glucose in and out of insulin sensitive cells and IRS1 mediates insulin signaling, the activities of each of these genes is expected to increase upon exposure to any chemical that increases insulin sensitivity, including butyric acid $[15,16]$. 
Understanding the mechanism by which various beneficial dietary components work is important in preventing new cases of DMT2 and in easing existing cases of the disease.

\section{Materials and Methods}

\subsection{Cell Culture}

Human primary subcutaneous pre-adipocytes were purchased from American Type Culture Collection (ATCC) and cultured in fibroblast media supplemented in low serum-fortified growth kit, as specifically recommended by ATCC in $37^{\circ} \mathrm{C}, 5 \% \mathrm{CO} 2$ incubator [17]. Medium was renewed every 24 to 48 hours and subcultured as needed.

\subsection{Insulin Shocking and Exposure of Cells to Butyric Acid}

$6.0 \times 104$ cells per well were seeded in a 96 well plate and insulin shocked with $5.6 \times 10-4 \mathrm{mg} / \mathrm{ml}$ insulin (Sigma) and $4.5 \mathrm{mg} / \mathrm{ml}$ glucose (Fisher Scientific) in supplemented fibroblast media (ATCC) for 24 hours [17]. Insulin shock suspensions were removed and replaced with $2.5 \times 10-8$ $\mathrm{mg} / \mathrm{ml}$ insulin and $2.1 \mathrm{mg} / \mathrm{ml}$ glucose along with the following concentrations of butyric acid (Sigma), each group in triplicate for 24 hours: $0 \mathrm{mg} / \mathrm{ml}$ (control group), $0.05 \mathrm{mg} / \mathrm{ml}, 0.1 \mathrm{mg} / \mathrm{ml}, 1.0 \mathrm{mg} / \mathrm{ml}$.

\subsection{RNA Extraction and Production of cDNA}

Suspensions were removed and RNA was extracted from cells using the RNeasy Mini Kit (Qiagen) and converted to complementary DNA (cDNA) using the RT2 First Strand Kit (Qiagen).

\subsection{Quantitative PCR and Analysis}

Quantitative polymerase chain reaction (PCR) was performed using the Applied Biosystems 7300 real-time PCR system with RT2 SYBR Green Mastermix (Qiagen) and GLUT4 (RefSeq accession number NM_001042.2) and IRS1 (RefSeq accession number NM_005544.2) primers (Qiagen). PCR settings were as follows: 1 cycle at $95^{\circ} \mathrm{C}$ for 10 minutes; 40 cycles of $95^{\circ} \mathrm{C}$ for 15 seconds and $60^{\circ} \mathrm{C}$ for 1 minute. Fold changes in gene expression for each group compared to the control group were determined using the $\Delta \Delta \mathrm{Ct}$ method (Qiagen) [18]. Human Rt2 RNA QC PCR Array was used as a control, with housekeeping genes actin, beta and hypoxanthine phosphoribosyltransferase 1 used to normalize data.

\section{Results}

After cells were insulin shocked and exposed in triplicate to $0.05 \mathrm{mg} / \mathrm{ml}, 0.10 \mathrm{mg} / \mathrm{ml}$, and $1.0 \mathrm{mg} / \mathrm{ml}$ of butyric acid, the GLUT4 and IRS1 genes were upregulated for all concentrations (Table 1). For GLUT4, the $0.1 \mathrm{mg} / \mathrm{ml}$ concentration resulted in the highest increase in expression, a 5.8 -fold upregulation $(\mathrm{p}<0.01)$. This was followed by a 4.2-fold upregulation in expression for $0.05 \mathrm{mg} / \mathrm{ml}$ butyric acid and a 2.7 -fold change in expression when $1.0 \mathrm{mg} / \mathrm{ml}$ butyric acid was used $(p<0.01)$. For IRS1, the lowest concentration $(0.05 \mathrm{mg} / \mathrm{ml})$ resulted in the greatest change in gene expression, a 6.0 -fold upregulation $(\mathrm{p}<0.01)$. This was followed by a 5.4 -fold increase for $0.1 \mathrm{mg} / \mathrm{ml}$ butyric acid, and 4.5 -fold change for $1.0 \mathrm{mg} / \mathrm{ml}$ butyric acid $(\mathrm{p}<0.01)$.

Table 1. Fold-changes in gene expression for glucose transporter 4 (GLUT4) and insulin receptor substrate 1 (IRS1) for each concentration of butyric acid $(\mathrm{mg} / \mathrm{ml})$ compared to the control $(\mathrm{n}=3)$

\begin{tabular}{|c|c|c|}
\hline & $\begin{array}{c}\text { Butyric acid } \\
\text { concentrations } \\
(\mathrm{mg} / \mathrm{ml})\end{array}$ & \\
\hline Genes: & 0.05 & 0.1 \\
\hline GLUT4 & 4.2 & 5.8 \\
\hline IRS1 & 6.0 & 5.4 \\
\hline
\end{tabular}

\section{Discussion}

This study indicates that butyric acid increases the expression of GLUT4 and IRS1 in human preadipocytes in vitro. All concentrations of butyric acid used in the study resulted in upregulations in expression of these genes. While the greatest increase coincided with $0.1 \mathrm{mg} / \mathrm{ml}$ butyric acid for GLUT4, the lowest concentration of butyric acid resulted in the greatest change in expression of IRS1. Interestingly, the lowest concentration tested is close to the level that has been shown to be nontoxic in plasma of human subjects. Conley et al., (1998) showed that 0.04 $\mathrm{mg} / \mathrm{ml}$ butyric acid in the plasma was safe for humans [19]. This means that a level of butyric acid that is safe in humans is likely to upregulate genes that are important to insulin sensitivity. This fatty acid holds great promise in the prevention of DMT2 for patients at risk and for treatment of those already suffering from it.

The effect on the expression of these genes is not as marked on human preadipocytes in vitro as the effect on human hepatocytes [14]. THLE-2 human hepatocytes exhibited a 9.1-fold upregulation of GLUT2 using 1.0 $\mathrm{mg} / \mathrm{ml}$ of butyric acid and a 15.8-fold upregulation of IRS1 using $0.05 \mathrm{mg} / \mathrm{ml}$ butyric acid. The lowest level of butyric acid tested $(0.05 \mathrm{mg} / \mathrm{ml})$ resulted in a 3.0 -fold upregulation of GLUT2, indicating that both genes are affected by the level that is close to that deemed by Conley et al. to be safe for humans. Altogether, human hepatocytes and preadipocytes have genes in the insulin pathway, glucose transporter genes and IRS1, which are increased in the presence of butyric acid. In other words, cells that are direct targets of insulin have increased sensitivity to insulin in the presence of safe levels of butyric acid.

Educating patients at risk for DMT2 on the best foods to 
eat to prevent the disease, along with increasing physical activity, is the best philosophy for prevention. Diets that include high fiber will increase butyric acid levels, which has been shown to ease symptoms in mice and rats with diabetes [11,12]. Butyric acid has also been shown to increase genes involved in the insulin pathway and thereby increase insulin sensitivity of cells that are insulin resistant in vitro. Collectively, these findings highlight the use of butyric acid in the prevention and treatment of DMT2.

\section{Conclusions}

This study showed that butyric acid increases the levels of the expression of GLUT4 and IRS1 in human preadipocytes in vitro. This research coincides with studies in rodents in vivo and in human intestinal and liver cells in vitro and supports the claim that this carboxylic acid increases insulin sensitivity. Boosting dietary fiber, and thereby the production of butyric acid, in the intestines can aid in the prevention and treatment of DMT2.

\section{Funding}

This research was funded by the Professional Development Committee at Winston-Salem State University and the NIGMS-RISE program at the Biomedical Research Infrastructure Center in Winston-Salem, NC.

\section{Conflicts of Interest}

There are no conflicts of interest.

\section{Acknowledgements}

I would like to gratefully acknowledge Dr. Aileru and his faculty at the Biomedical Research Infrastructure Center, the Department of Clinical Laboratory Science, and the Professional Development Committee at Winston-Salem State University for funding and support of this research.

\section{REFERENCES}

[1] American Diabetes Association (ADA). Statistics about Diabetes, 2016. Available online from http://www.diabetes.o $\mathrm{rg}$ /diabetes-basics/statistics/

[2] American Diabetes Association (ADA). Complications, 2016. Available online from http://www.diabetes.org/living-with-d iabetes/complications/

[3] A. Auchincloss, A. Roux, M. Mujahid, M. Shen, A. Bertoni, M. Carnethon. Neighborhood resources for physical Activity and healthy foods and incidence of type 2 diabetes mellitus: the multi-ethnic study of atherosclerosis, Archives of Internal
Medicine, Vol.169, No.18, 1698-1704, 2009.

[4] A. Pituch, J. Walkowiak, A. Banaszkiewicz. Butyric acid in functional constipation, Przeglad Gastroenteologiczny, Vol.8, No.5, 295-298, 2013.

[5] J. Wong, R. de Souza, C. Kendall, A. Emam, D. Jenkins. Colonic health: fermentation and short chain fatty acids, Journal of Clinical Gastroenterology, Vol.40, No.3, 235-243, 2006.

[6] S. Duncan, A. Belenquer, G. Holtrop, A. Johnstone, H. Flint, G. Lobley. Reduced dietary intake of carbohydrates by obese subjects results in decreased concentrations of butyrate and butyrate-producing bacteria in feces, Applied and Environmental Microbiology, Vol.73, No.4, 1073-1078, 2007.

[7] G. Jakobsdottir, J. Xu, G. Molin, S. Ahrne, M. Nyman. High-fat diet reduces the formation of butyrate, but increases succinate, inflammation, liver fat and cholesterol in rats, while dietary fibre counteracts these effects, PLOS ONE, Vol. 8, No. 11, e80476, 2013.

[8] L. Boffa, J. Lupton, M. Mariana, M. Ceppi, H. Newmark, A. Scalmati, M. LipkinModulation of colonic epithelial cell proliferation, histone acetylation, and luminal short chain fatty acids by variation of dietary fiber (wheat bran) in rats, Cancer Research, Vol. 52, No.21, 5906-5912, 1992.

[9] P. Mortensen, J. Andersen, S. Arffmann, E. Krag. Short-Chain Fatty Acids and the Irritable Bowel Syndrome: The Effect of Wheat Bran Scandinavian Journal of Gastroenterology, Vol.22, No.2, 185-192, 1987.

[10] P. Pouillart. Role of butyric acid and its derivatives in the treatment of colorectal cancer and hemoglobinopathies, Life Sciences, Vol.63, No.20, 1739-1760, 1998.

[11] Z. Gao, J. Yin, J. Zhang, R. Ward, R. Martin, M. Lefevre, W. Cefalu, J. Ye. Butyrate improves insulin sensitivity and increases energy expenditure in mice, Diabetes, Vol.58, No.7, 1509-1517, 2009.

[12] C. Kumar, K. Rachappaji, C. Nandini, K. Sambaiah, O. Salimath. Modulatory effect of butyric acid- a product of dietary fiber fermentation in experimentally induced diabetic rats, The Journal of Nutritional Biochemistry, Vol.13, No.9, 522-527, 2002.

[13] F. De Vadder, P. Kovatcheva-Datchary, D. Goncalves, J. Vinera, C. Zitoun, A. Duchampt F. Backhed, G. Mithieux. Microbiota-generated metabolites promote metabolic benefits via gut-brain neural circuits, Cell, Vol.156, No.1-2, 84-96, 2014.

[14] L. Maness. The effect of butyric acid on gene expression of GLUT2 and IRS1 on human hepatocytes in vitro, Advances in Diabetes and Metabolism, Vol.3, No.1, 7-10, 2015.

[15] R. Govers, A. Coster, D. James. Insulin increases cell surface GLUT4 levels by dose dependently discharging GLUT4 into a cell surface recycling pathway, Molecular and Cellular Biology, Vol.24, No. 14, 6456-6466, 2004.

[16] J. Tomlinson, A. Boudreau, D. Wu, H. Salem, A. Carrigan, A. Gagnon, A. Mears, A. Sorisky, E. Atlas, R. Haché. Insulin sensitization of human preadipocytes through glucocorticoid hormone induction of forkhead transcription factors, Molecular Endocrinology, Vol.24, No.1, 104-113, 2010. 
[17] American Type Culture Collection (ATCC). Manassas, VA, 2014. Online available from http://www.atcc.org/Products/A 11/CRL-2706.aspx\#culturemethod

[18] Qiagen. Valencia, CA, 2014. Online available from https://www.qiagen.com/us/?UID=674da061-b502-45b0-80b

\section{$4-\mathrm{d} 8 \mathrm{a} 564 \mathrm{~d} 3 \mathrm{ea} 00$}

[19] B. Conley, M. Egorin, N. Tait, D. Rosen, E. Sausville, G. Dover, R. Fram, D. Van Echo. Phase I study of the orally administered butyrate prodrug, tributyrin, in patients with solid tumors, Clinical Cancer Research, Vol.4, 629-634, 1998. 